Published in final edited form as:

N Engl J Med. 2013 October 31; 369(18): 1766-1767. doi:10.1056/NEJMc1310369.

\title{
The author replies
}

\author{
Jeffrey I. Cohen, M.D. \\ Medical Virology Section, Laboratory of Infectious Diseases, National Institutes of Health, \\ Bethesda, MD \\ Jeffrey I. Cohen: jcohen@niaid.nih.gov
}

\begin{abstract}
Hirschmann asks about the basis of the Advisory Committee on Immunization Practices' recommendation that persons with a history of zoster be vaccinated. Reasons for vaccinating such persons include (a) lack of certainty about the validity of a prior history of zoster, (b) uncertainty about the degree and duration of protection from prior zoster, and (c) safety of giving vaccine to persons with a history of zoster (1). While the risk of recurrent zoster is low during the first few years after zoster, the risk likely increases with time as VZVspecific cell immunity declines. Thus, one might delay vaccination for a few years after a well-documented case of zoster.
\end{abstract}

Katz points out that acute zoster pain may not respond to conventional therapy and suggests that injection of a local anesthetic with or without corticosteroids may reduce pain. Makharita et al. (2) recently performed a controlled, double-blind trial of repeat ganglion blockade injections in patients with zoster already receiving gabapentin and acknowledged that injections can potentially have serious complications and that a multicenter trial is needed to confirm their promising results. New treatments, tested in controlled trials, are needed for pain associated with zoster.

Fried raises an important question regarding the safety and efficacy of zoster vaccine in persons $>80$ years old. No significant difference was noted in the rate of serious adverse events in persons $\geq 80$ years old in the Shingles Prevention Study (SPS) who received the vaccine versus those who received placebo (3). In another study, the relative risk of serious adverse events within 42 days of receiving zoster vaccine was 1.66 for subjects ages $60-69$, 1.03 for those ages $70-79$, and 1.18 for those ages 280 (4). Thus, the vaccine does not appear to be less safe in the elderly.

The SPS showed that while the efficacy of zoster vaccine to prevent shingles was reduced in older persons, the efficacy of the vaccine to prevent postherpetic neuralgia (PHN) did not decline in persons $\geq 70$ years old (5). While the zoster vaccine package insert indicates that the efficacy of the vaccine to prevent PHN was lower in persons $\geq 80$ years old, the total number of cases of PHN was very small $(\mathrm{N}=7)$. Since the elderly have the highest frequency of both zoster and PHN, they would be expected to receive the most benefit from the vaccine, even if its efficacy were modestly reduced compared to that in younger persons.

\section{References}

1. Morrison VA, Oxman MN, Levin MJ, et al. Safety of zoster vaccine in elderly adults following documented herpes zoster. J Infect Dis. 2013; 208:559-63. [PubMed: 23633406] 
2. Makharita MY, Amr YM, El-Bayoumy Y. Effect of early stellate ganglion blockade for facial pain from acute herpes zoster and incidence of postherpetic neuralgia. Pain Physician. 2012; 15:467-74. [PubMed: 23159962]

3. Simberkoff MS, Arbeit RD, Johnson GR, et al. Shingles Prevention Study Group. Safety of herpes zoster vaccine in the shingles prevention study: a randomized trial. Ann Intern Med. 2010; 152:54554. [PubMed: 20439572]

4. Murray AV, Reisinger KS, Kerzner B, et al. Safety and tolerability of zoster vaccine in adults $\geq 60$ years old. Hum Vaccin. 2011; 7:1130-6. [PubMed: 22048110]

5. Oxman MN, Levin MJ, Johnson GR, et al. A vaccine to prevent herpes zoster and postherpetic neuralgia in older adults. N Engl J Med. 2005; 352:2271-84. [PubMed: 15930418] 